\title{
The Feasibility Analysis of All-in-one Teaching Mode of Public PE Elective Course in Universities
}

\author{
Gaosheng Li \\ Public Basic Course Department \\ Wuhan Technology and Business University \\ Wuhan, P.R.China
}

\begin{abstract}
With the quick development of national educational system reform, many universities begin to try some new ways in different teaching activities. The thesis focuses on the study of the teaching mode of public PE elective courses of some universities. It tries to solve the problems in public PE elective courses and provides some relevant analysis of the feasibility of all-in-one elective courses of public $P E$ in universities. It aims at providing some practical experience in the reform of teaching mode of elective courses of public PE.
\end{abstract}

Keywords-common universities; all-in-one; public PE; elective course

\section{INTRODUCTION}

The ministry of education issued National College Physical Education Curriculum Teaching Guide in 2002, which indicated that PE is an important tool to implement the quality education and foster the talented people. PE should put students first and take into consideration college students' body and mind situation and their interests. PE also should meet the needs of students' individual development and lay the foundation for students' lifetime exercises to strengthen their body, improve their health and enhance their PE awareness. PE elective courses break the traditional PE teaching modes and bring great changes to current $\mathrm{PE}$ teaching. In terms of the present situation of elective courses, some following problems exist: some universities has implemented PE elective courses for a very short time in some aspects; teachers are imbalanced in professional teaching skills and even some teachers are very poor in professional teaching skills; students have very poor PE knowledge and show very little interest; some universities didn't set up the teaching system for elective courses; PE elective courses teaching put more emphasis on imparting skills than learning theoretical knowledge. To change the present situation of PE elective courses and promote the reform of teaching modes of PE elective courses, it is very necessary to carry out the all-in-one teaching mode.

\section{RESEARCHING SUBJECT AND METHOD}

\section{A. Researching Subject}

The researching subject is the teaching mode of PE elective courses in ordinary undergraduate universities in a given province.

\section{B. Researching Methods}

1) Literature Review: Several PE books, including Introduction to Physical Education, School Physical Education, Psychology of Physical Education, Brief Discussion on the Teaching of the Elective Course of Public Physical Education, are carefully consulted. Meanwhile, a considerable number of literatures have been searched on these websites: China journal NET, VIP Journal Net and Wanfang Database, which has laid strong foundations for the research.

2) Questionnaire: To search for true and effective information, under the guide of the experts, two different questionnaires are designed, including teachers' questionnaire and students' questionnaire, according to the designing rules of questionnaire.

3) Mathematical Statistics: The relevant statistical softwares, like Excel, are used to analyze the data collected by using questionnaires and then the corresponding results are achieved.

\section{The EXPLANATIONS OF ALL-IN-ONE PUBLIC Physical EduCATION Elective COURSE MODES}

\section{A. The Definition of All-in-One Public Physical Education Elective Course Modes}

Integration is a form of public physical education elective course teaching, not the set mode. The definition of all-in-one public physical education elective course modes is different according to the analysis in different angles. All-in-one teaching mode involves different teaching aims and different teaching contents.

Based on different theories, all-in-one public physical education elective course mode refers to the teaching-centered and multi-aiding mode of putting students' extracurricular physical exercises into credit management system.

\section{B. The Explanations of All-in-One Public Physical Education Elective Course Modes}

To be specific, some PE classes carry out class teaching activities of argument type, discussion type and group type, in order to enhance students' learning initiative and achieve good teaching results. 
Other PE classes are led by schools to organize small-scale extracurricular PE activities which correspond with the course teaching and are directed by professional teachers, including morning exercises, PE association activities, small-scale PE matches. Students will be given certain credits if they reach the set standards and pass the tests, which can help realize the mode of connecting class teaching and after-class exercises.

\section{RESULTS AND ANALYSIS}

\section{A. The Strong Support of Different National Policies}

The ministry of education indicated in 2002 that class teaching should be closely connected with after-class and out-of-school PE activities to realize the aim of public physical education elective courses.

The Third Plenary Session of the 18th CPC Central Committee in 2013 has passed the decision of the Central Committee of the Communist Party of China on major issues concerning comprehensively deepening the reform, which indicated that PE classes and extracurricular exercises should be strengthened to promote the healthy body and mind of young people. This demand is thought-provoking and has a deep effect on our PE reform and development.

The ministry of education has issued the job outline of 2014, which emphasizes that school PE work should be strengthened to realize the plan of promoting young people's body health and further the development of sunshine PE activities.

The above policies have provided the strong support for the reform and development of elective course mode of all-in-one public physical education.

\section{B. The Powerful Guarantee of Teachers' Professional Attainment}

PE teachers' professional attainment, in some way, provides strong guarantee for the further study of students' sport skills. If PE teachers involve themselves into the direction of students' after-class PE activities, students' initiative of participating in PE activities will be greatly improved. In the teaching mode of all-in-one public PE elective courses, after-class PE activities with the guidance of professional teachers are included in the course system. Therefore, PE teachers should have deep professional attainment to make sure of students' learning effects of after-class PE activities, which lays a good foundation for the buildup of the teaching mode of all-in-one public PE elective courses.

\section{The Basic Guarantee of School PE Facilities}

PE facilities are the basic guarantee of the implementation of public physical education elective course. Enough PE facilities lay a good foundation for the multiple development of public PE elective course. Some relevant materials showed that common universities in our country have perfect PE facilities. Common universities make full use of social resources and pour a lot of money into the building of PE facilities, which provide a basic guarantee for the implementation of public physical education elective course.

\section{The Real Need of Students' Credit System}

Nowadays, credit system has been carried out in the universities of our country, which makes getting the credits become the main purpose of many students participating into the learning of public PE elective course and neglecting the after-class PE activities without credits. If credit system will be carried out in after-school PE activities, students can get credits when participating into PE activities. It will be a win-win result.

In the teaching mode of all-in-one public PE elective courses, the implementation of creative credit system meets the aim of students' after-class PE activities and enhances the students' initiative and enthusiasm. In other words, students' real need of credit system lays a good foundation for the building of the teaching mode of all-in-one public PE elective course.

\section{RESULTS AND SUGGESTIONS}

\section{A. Building the Rules from the Top down}

In the teaching mode of all-in-one public PE elective courses, after-class PE activities should be participated in by all students in the school. Therefore, it is very important for school leaders to support and pay attention to after-class PE activities. The school leaders should make a good plan for the whole course system and raise the rate of making use of $\mathrm{PE}$ resources to ensure the implementation of the teaching mode of all-in-one public PE elective courses.

Building the complete rules is an important way to ensure the implementation of the teaching mode of all-in-one public PE elective courses. The building of the rules should not only consider the constraints and encouragements, but also include the recognition and reward of teachers' responsibility and workload. Perfect rules can promote the implementation of the teaching mode and the healthy development of the mode.

\section{B. Getting Rid of Barriers and Collaborating with Each Other}

In traditional process of implementing public PE elective courses, the universities or different departments arranged the teaching hours of PE elective courses according to the whole teaching plan, then PE teachers set up their course contents and finally gave the students' scores back to different departments to be included in the credit system.

The teaching mode of all-in-one public PE elective courses needs the co-organization and management of the whole university and all departments, which needs all departments or different parts to get rid of barriers and collaborate with one another to ensure the implementation of the teaching mode of all-in-one public PE elective courses.

\section{Doing Some Research and Opening Classes according to Students' Needs}

To ensure the effective implementation of the teaching mode of all-in-one public PE elective courses, enhance 
students' initiative of participating into PE activities, give full play to the basic functions of PE and avoid the waste of PE resources, all schools should do some research into students' sport interests, numbers of sports venues and professional skills of PE teachers and get the detailed materials and accurate data before the implementation of the teaching mode of all-in-one public PE elective courses.

On the basis of comprehensive analysis, the evaluation should be made on students' sports needs and actual PE resources and classes should be opened according to students' needs to avoid the blindness of the course design. In this way, the pertinence and practicability of the teaching mode of all-in-one public PE elective courses will be effectively improved and more importantly, the direction will be provided for the development of the teaching mode.

\section{REFERENCES}

[1] Mao Zhenming. Brief Discussion on the Teaching of the Elective Course of Public Physical Education[M]. Beijing: Beijing Normal University Press, 2009:16.

[2] Yang Wenxuan, Yang Ting. Introduction to Physical Education[M]. Beijing: Higher Education Press, 2005:70-71.

[3] Zeng Yongzhong, Dong Lunhong. Public PE Elective Courses System Reform and Building Research[M]. Wuhan: China Central Normal University publishing house, 2009:86.

[4] Wu Ming. The Survey and Analysis of College Students' Needs for PE Theoretical Knowledge in Common Universities[J]. Shandong Sports Science \& Technology, 2001,23 (3) : 43-45.

[5] Pan Shaowei, Yu Kehong. School Physical Education[M]. the second edition. Beijing: Higher Education Press, 2008:178.

[6] Zhao Junhao, Zhang Junyong. The Comparative Analysis of PE Teaching Mode and Course Goal of Chinese and Foreign Universities in the New Century[J]. Journal of Hubei Water Resources Technical College, 2011,7 (1) :37. 